\title{
Damian Herda
}

\section{On Metonymically Motivated Delexicalization of Quantifying Nouns in English and Polish: A Corpus Investigation}

\begin{abstract}
Drawing on corpus data, this paper investigates the hypothesis that the delexicalization of the English nouns pile and stack as well as their Polish counterparts sterta 'pile' and stos 'stack', evidenced by collocational expansion, is to a considerable extent fuelled by the conceptual contiguity between their prototypical concrete N2-collocates and certain abstract notions which may be instantiated by means thereof. It is postulated that this metonymic relation leads to the items gradually loosening their original selectional requirements, thereby contributing to the schematization of their source semantics. The results of an empirical analysis show that the collocational broadening of all of the nouns under scrutiny indeed largely stems from metonymization, yet the tendency is more pronounced in the case of the Polish items, particularly stos 'stack'. This finding can be accounted for in view of the fact that in contrast to their English equivalents, they have not yet established themselves as schematic quantifiers, as corroborated by their current dictionary definitions, and therefore still heavily rely on the aforementioned conceptual mechanism in their delexicalization.
\end{abstract}

\section{Keywords}

quantifying noun, indefinite quantifier, grammaticalization, delexicalization, collocation, metonymy

\section{Streszczenie}

Bazując na danych zaczerpniętych z korpusów językowych, niniejszy artykuł stawia sobie za cel weryfikację hipotezy, zgodnie z którą deleksykalizacja angielskich rzeczowników pile 'sterta' i stack 'stos' oraz ich polskich odpowiedników sterta i stos, uwydatniająca się rozszerzoną kolokacyjnością, jest w znacznym stopniu motywowana związkiem metonimicznym między ich regularnymi kolokatami konkretnymi a pewnymi pojęciami abstrakcyjnymi, które mogą zostać skonkretyzowane za ich pomocą. Zakłada się mianowicie, że owa relacja konceptualna prowadzi do stopniowego rozluźnienia pierwotnych wymogów selekcyjnych badanych leksemów, odgrywając zarazem istotną rolę w schematyzacji ich wyjściowej semantyki. Wyniki analizy empirycznej wskazują, że ekspansja kolokacyjna analizowanych elementów leksykalnych faktycznie w dużej mierze opiera się na metonimi- 
zacji, tendencja ta jest jednak wyraźniejsza w przypadku polskich rzeczowników, zwłaszcza stos, co można wyjaśnić tym, że w odróżnieniu od swoich angielskich ekwiwalentów nie skonwencjonalizowały się one jeszcze - co potwierdzają obecne definicje słownikowe obu jednostek - w funkcji liczebników nieokreślonych, toteż ich deleksykalizacja wciąż jest napędzana głównie opisanym wyżej mechanizmem konceptualnym.

\section{Słowa kluczowe}

rzeczownik ilościowy, liczebnik nieokreślony, gramatykalizacja, deleksykalizacja, kolokacja, metonimia

\section{Introduction}

Aside from the canonical quantifiers many/much and duzo/wiele 'many; much', expressing large numbers or amounts, English and Polish possess a set of nouns which may perform the function of indefinite quantification (cf., among others, Schabowska 1967; Biber et al. 1999), especially when employed in the binominal construction schematized as 'N1 of N2' in English and 'N1 N2.GEN' in Polish, wherein N1 stands for the quantifying noun $(\mathrm{QN})$, and N2 refers to the concomitant nominal whose referent is being assessed in terms of quantity. Examples include items such as load and bunch as well as fura 'load' and masa 'mass.' However, despite their functional closeness, such elements have been observed to exhibit specific preferences as to what types of N2s they quantify over, a fact which can be elucidated in terms of their distinct source semantics (cf. Brems 2003, 2011; Delbecque and Verveckken 2014).

Examining the collocational profile of the non-standard English quantifier pile(s) of, Brems (2003: 306-307) notes that a fair number of its abstract N2-collocates, e.g. details, denote concepts associatively linked to the referents of the concrete nouns with which the item prototypically co-occurs, such as papers or banknotes. Since metonymy is traditionally defined as relying on the relation of contiguity, understood as "a relationship of association that does not involve similarity" (Feyaerts 2003: 63; cf. also Nerlich 2006; Dirven and Radden 2007; Kövecses 2010), the above-described conceptual mechanism whereby certain N2s are licensed by virtue of their associative relation to concrete stuff, in particular (sheets of) paper, can be taken to have a metonymic character. More importantly, it is hypothesized that this so-called paper metonymy promotes the purely quantificational uses of pile, thus playing a significant role in its grammaticalization into an absolute quantifier (cf. Brems 2003, 2011):

(1) a pile of papers with information (a set of papers arranged into a pile or a large quantity of papers, and hence also of information) $>$ a pile of information (a large amount of information as such, whether expressed on paper or not). 
The present paper sets out to test the aforementioned hypothesis based on the collocational analysis of two English near-synonymous QNs, namely pile and stack, and their Polish equivalents, sterta 'pile' and stos 'stack', respectively. What should be underlined here is the fact that whereas the English items have already gained the status of quantifiers, as corroborated by their dictionary definitions (cf. OALD, pp. 1145, 1499), the Polish ones are still typically used in their basic senses related to a specific constellation of entities (cf. USJP, pp. $533,544)$. On the basis of corpus-derived data, it is argued here that the latter's collocational expansion to non-concrete nominals, accompanied by a shift towards a purely quantificational meaning, indeed relies on the metonymic relation between their regular concrete N2-collocates and some abstract notions capable of being instantiated by means of paper, which corroborates the hypothesis put forward by Brems $(2003,2011)$.

The structure of the paper is as follows. Section 2 offers basic information on the semantics of quantifiers. Section 3 provides a brief outline of the grammaticalization of nouns into quantifiers, with a focus on the initial stage of this process, labelled here as delexicalization. Section 4, in turn, encompasses an account of the research hypothesis, a description of the sources of the empirical data and the applied methodology, as well as a presentation of the results of the analysis carried out on material extracted from language corpora, illustrated with a number of authentic examples. The main observations arrived at in the study are summarized in section 5 .

\section{Quantifiers: basic facts ${ }^{1}$}

Following Langacker (1991: 81), quantifiers may be defined as linguistic items whose function consists in indicating "the size of the profiled instance." Normally, they occur in prenominal position, e.g. few in few rooms, yet may also function as pronouns, as is the case with many in Many have passed the examination.

From a semantic standpoint, it is possible to identify two broad categories of quantifiers, namely relative, also known as set quantifiers, and absolute or scalar quanifiers (Langacker 1991; Dirven and Radden 2007). Those belonging

${ }^{1}$ The terminology provided in this section principally comes from the English literature, the reason being that the treatment of native quantifying elements in Polish is marked by a high degree of terminological inconsistency, as their classification depends on whether one takes into account morphological, syntactic, or solely semantic criteria (cf. Siuciak 2008). The item troche 'a little', for instance, is labelled as an adverb in Doroszewski (1952), as an indefinite partitive quantifier in Laskowski (1984), as an indefinite quantifier in Schabowska (1967), while in ISJP and USJP, it is referred to as a quantifying pronoun. For an overview of the pertinent problems, see Siuciak (2008: 10-15), Derwojedowa and Kopcińska (2009), and Kozioł (2016). 
to the former type "specify a quantity in relation to a reference mass" which comprises the maximal instantiation of the relevant category (Langacker 1991: 82), thus invoking the image of a full set and a subset, e.g. all, half, and most. The latter, on the other hand, are different in that they do not refer to the maximal extension of the pertinent category, i.e. a quantitative assessment is made on the basis of "a scale with some implicit norm or standard" (Dirven and Radden 2007: 117), e.g. many, several, or seven.

As Langacker (1991: 84) further observes, quantifiers may likewise be classified in accordance with the countability of the nominals which they accompany. Thus, the following typology can be constructed: (i) the quantifier one, occurring exclusively with singular nouns, (ii) quantifiers co-occurring with non-plural mass nouns, e.g. much, little, a little, and (iii) quantifiers used in relation to plural nouns, e.g. many, few, a few. ${ }^{2}$ An analogous classification is proposed by Dirven and Radden (2007: 131), who draw a distinction between number quantification, which pertains to multiplex instances, i.e. count nouns, and amount quantification, peculiar to substance instances, i.e. mass nouns.

In addition, Quirk et al. (1985: 264) and Delbecque and Verveckken (2014) recognize yet another, large group of quantifying expressions, referred to as phrasal or binominal quantifiers, e.g. pile of in a pile of money. Similarly, Dirven and Radden (2007: 133) state that in English, there exists an open-ended set of lexical items exhibiting potential for indefinite absolute quantification, i.e. conveying a subjective assessment as to the quantity of what the accompanying nominal refers to, e.g. heap(s) of and mountain(s) of. In Biber et al. (1999: 252-255), the elements occupying the N1-slot in binominal syntagms of this type are called quantifying nouns, a name which roughly corresponds to the Polish term rzeczownik ilościowy 'quantitative noun' in Schabowska (1967). As Langacker (1991: 88) points out, such lexemes have "taken on a different sense in which size becomes the most salient specification," so that "the notion of a discrete physical object has faded, leaving behind the conception of a schematically characterized mass."

Crucially, the development of schematic quantifier meanings in nominal elements may be considered the outcome of various diachronic processes, which can be broadly labelled as grammaticalization (cf., among others, Brems 2003, 2011; Traugott and Trousdale 2013; Delbecque and Verveckken 2014). The following section will therefore seek to shed light on the linguistic phenomenon at issue, in particular on its initial stage, i.e. delexicalization.

\footnotetext{
${ }^{2}$ Notably, Polish indefinite quantifiers do not exhibit as much sensitivity towards the countability status of the nominals with which they co-occur as the English ones, since there are only a few items which are compatible either only with countable or only with uncountable nouns, e.g. kilka 'a few' can appear exclusively alongside a pluralized count noun, whereas both $d u \dot{z} o$ 'many; much' and mato 'few; little' can be used in relation to count as well as non-count nouns.
} 


\section{Delexicalization of QNs}

As stated above, the emergence of non-standard quantifiers such pile(s) of or stack(s) of is connected with the notion of grammaticalization. ${ }^{3}$ Following Hopper and Traugott (2003:1-2), the term in question refers to a process whereby lexical items and constructions which possess content meanings develop grammatical, i.e. more abstract and schematic, senses in specific contexts, and grammatical elements come to serve novel grammatical functions over time.

The basic phenomenon indicative of incipient grammaticalization is traditionally known as semantic bleaching ${ }^{4}$ (Sweetser 1988; Heine 2003; Hopper and Traugott 2003), a term which explicitly points to an assumed semantic impoverishment of the grammaticalizing item. However, Hopper and Traugott (2003: 94) argue that at least at the onset of the grammaticalization process, "there is a redistribution or shift, not a loss, of meaning." Brems (2011) subscribes to this lossand-gain approach too, maintaining that phrases such as pile(s) of invite quantity inferences with a simultaneous backgrounding of the constellation aspect inherent in their lexical semantics, so that the inferred meaning components become semantically more relevant at the expense of the less salient ones. In consequence, we can speak of "an overall redistribution of meaning" rather than semantic attenuation (Brems 2011: 103; cf. also Schabowska 1962; Sweetser 1988). ${ }^{5}$

In view of the partial inadequacy of the aforementioned terminology suggesting a general grammaticalization-induced decrease in meaning, Brems (2011: 103-105) proposes that the development of novel quantifiers of this kind should be more accurately analysed as an instance of delexicalization, understood primarily as semantic generalization, and transparently mirrored in the extended collocability of the pertinent items, which renders the very concept empirically verifiable. ${ }^{6}$ The principal diagnostic test on the basis of which to establish whether a given item may be taken to function purely quantificationally

\footnotetext{
${ }^{3}$ In Polish linguistic tradition, the grammaticalizalization of nouns into quantifiers is typically referred to as numeralization (cf., among others, Schabowska 1962, 1967).

${ }^{4}$ Alternative terms are semantic attrition (Lehmann 1985) and semantic reduction (Heine 2003).

${ }^{5}$ The term bleaching, in turn, more accurately describes a situation whereby the grammaticalizing item has indeed been bereft of its original sense(s) to the benefit of a more abstract, schematic one. An example may be the Polish quantifier troche 'a little' (cf. Schabowska 1970), etymologically related to the Proto-Slavonic form *troska, originally meaning 'bit; chip; scrap' (SEJP, p. 642).

${ }^{6}$ According to Brems (2003: 291-292), delexicalization normally precedes the actual grammatical reanalysis of a QN as a quantifier. The syntactic status of QNs is nevertheless more problematic to determine empirically due to a scarcity of its formal reflexes. For instance, what may serve as a formal indicator of the syntactic reanalysis of such items in English are changes in verb agreement, as illustrated by (i) and (ii):

(i) There are a pile of questions.

(ii) Stacks of time was devoted to this issue.

Yet, this structural reflex only applies to binominal syntagms which occur in the subject position, and exclusively to those in which the first and the second nominal element differ in number.
} 
in a particular contextual setting involves the possibility of replacing it with a standard equivalent, i.e. much, many, or lot(s) of in English, and dużo/wiele 'many; much' or mnóstwo 'lot(s) of' in Polish (cf. Brems 2011: 229). What deserves special attention here is that in their quantifier uses, the relevant elements can be modified by a limited set of adjectives, namely only by those which reinforce the quantity reading, especially whole in English and caly 'whole' in Polish (cf. English a whole/great lot of and Polish całe mnóstwo 'a whole lot of'). ${ }^{7} \mathrm{How}$ ever, unlike the canonical quantifiers, QNs can be preceded by demonstrative and possessive determiners, and in English, also by the definite article, which serves in such cases as an anaphoric determiner (cf. Brems 2003, 2011; Traugott and Trousdale 2013; Delbecque and Verveckken 2014).

\section{Analysis of empirical data}

\subsection{Hypothesis}

Following Brems $(2003,2011)$, the hypothesis entertained in this paper is that a considerable percentage of the abstract N2-collocates of the English QNs pile and stack as well as their Polish counterparts sterta 'pile' and stos 'stack' in their purely quantificational uses should encompass nouns metonymically related to (stackable) paper in that the abstract nominals are either intrinsically associated with tangible paper entities, as is the case with $\operatorname{debt}(s)$ and loans, habitually expressed or otherwise instantiated by means of paper, e.g. information or study, or at least capable of being easily verbalized, and hence also concretized in paper form. This assumption stems from the fact that, in the concrete domain, the QNs all exhibit a conspicuous tendency to co-occur with nouns referring to paper objects, such as books, papers, documents, leaflets, or banknotes. However, whereas the English items have already established themselves as quantifiers (cf. OALD), the 'large quantity' sense is still absent from the dictionary definitions of the Polish ones (cf. SJP PWN; USJP), as shown in sections 4.4.1-4.4.4 below. Thus, it may be expeced that the former, whose grammaticalization, manifesting itself in conventionalized semantic generalization, has reached a more advanced stage, will display a wider range of semantically diverse N2-collocates, while the latter's collocational expansion is fuelled by paper metonymy to a greater extent, which should be reflected in a higher proportion of abstract noun collocates of this kind attested for sterta 'pile' and stos 'stack' than for pile and stack.

${ }^{7}$ Given their restricted premodification patterns, QNs may be said to have undergone partial decategorialization, i.e. they are gradually becoming devoid of the properties of the class of nouns (cf. Brems 2011: 111). 


\subsection{Presentation of the corpora}

The Polish data were extracted from the National Corpus of Polish (henceforth NKJP), a 300 million word collection of texts representing different registers. The English material, on the other hand, comes from a number of smaller corpora, namely the 100 million word British National Corpus (henceforth BNC), the TIME Magazine Corpus of American English (henceforth TIME), equally large as the BNC, the 50 million word Strathy Corpus of Canadian English (henceforth CAN), and finally, the Corpus of Online Registers of English (henceforth CORE), also consisting of approximately 50 million tokens. As can be noted, the total size of all the above-listed English corpora corresponds to that of the Polish one, and moreover, both the English and the Polish material is register-diversified. Besides, the English data represent different regional varieties, which contributes to a balanced picture of the general use of QNs. ${ }^{8}$

\subsection{Methodology}

The data extraction procedure progressed as follows. First, the nouns selected for the investigation were typed into the corpus search engine in their singular and then plural forms together with the preposition of in English, and the command [cas="gen"] in Polish, ${ }^{9}$ thanks to which the item following the QN was in the genitive case, and the $\mathrm{N} 2$ could be preceded by various modifiers. ${ }^{10}$

The next stage of the data collection process consisted in the manual edition of the extracted material. First of all, it was necessary to eliminate the examples in which the $\mathrm{N} 1$ had been used in a sense other than the arrangement/ quantity one. Likewise, for the sake of clarity, the syntagms in which the N2slot was occupied by a pronoun were excluded as well, since it was not always possible to determine its actual reference. It was also essential to remove occasional repetitions of the same utterance as well as a few examples representative of highly specialized registers, notably the IT one, e.g. stos modyfikatorów 'a stack of modifiers'. The examples eliminated at this point were then not taken into account in the quantitative examination of the data.

${ }^{8}$ Some QNs are more frequently attested in specific varieties of English. For instance, the quantifier stack(s) of exhibits a higher frequency of use in British English (cf. OALD). As this study looks into general principles of delexicalization, the data for this research have been purposefully gathered from different varieties of English to avoid such accidental biases.

${ }^{9}$ This stems from the fact that the singular forms of QNs sometimes show slightly different collocational preferences than the plural ones (cf., among others, Brems 2003, 2011; Traugott and Trousdale 2013).

${ }^{10}$ The Polish data were extracted by means of the Poliqarp search engine. 
The core of the analysis was the identification of the abstract N2-collocates of each item. ${ }^{11}$ Crucially, the abstract noun collocates were then searched for so-called pure quantifier uses (PQUs), i.e. instances where the context (or rather co-text) of occurrence allows us to treat the $\mathrm{N} 1$ as semantically equivalent to and thus replacable with a standard quantifier without distorting the intended meaning (cf. Brems 2011: 229). In such cases, pile/stack/sterta 'pile'/ stos 'stack' serve to indicate a considerable quantity of the abstraction(s) denoted by the N2, without there (necessarily) being any actual piles or stacks. Accordingly, instances in which a given abstract N2 clearly refers to sheets of paper on which some abstract notion has been expressed and the $\mathrm{N} 1$ most possibly still designates a specific configuration, as is the case with (2), were filtered out:

(2) Two days later Treasury Secretary Henry Morgenthau told the U.S. the other half. Mr. Morgenthau corralled the Congressional leaders, laid before them a stack of indigestible truths, told them to swallow hard. [TIME]

Also excluded were examples in which the literal frame of the analysed N1s is explicitly re-invoked, e.g. by means of verbs denoting vertical movement, such as rise or its Polish equivalent rosnać ć 'rise', including their various derivatives: ${ }^{12}$

(3) Leczenie nie wiedzie się mimo rosnącej sterty wyszukanych badań i stosowania najnowszych specyfików. [NKJP]

'The treatment is not successful despite a rising pile of sophisticated medical examinations and the use of the latest medications. ${ }^{13}$

So-called valuing quantifier uses (cf. Brems 2011: 175), in which the N1 functions as a negatively loaded collective noun rather than a schematic quantifier, were sifted out as well: ${ }^{14}$

${ }^{11}$ However, the boundaries between concrete and abstract nominals are sometimes not clear-cut, and moreover, there exist nouns whose status can only be determined on the basis of the context of use, such as things and stuff (Polish rzeczy). This problem also applies to nouns denoting abstract concepts, mostly communicative acts, which are frequently concretized by means of paper, e.g. complaint or offer. In such cases, if the context unambiguously pointed to the existence of actual sheets of paper on which notions of this kind are expressed, the pertinent example was subsumed under the concrete category. However, epistemic and evidential nominals, such as data, information, or evidence, were invariably classified as abstract.

${ }_{12}$ As already suggested by Brems (2003), uses of this sort may be considered a transitory stage in the grammaticalization of nouns into pure quantifiers.

${ }^{13}$ The translations of the Polish examples and of the dictionary definitions of sterta 'pile' and stos 'stack' are all mine (DH).

${ }^{14}$ In some contexts, however, it is problematic to distinguish between purely quantificational and evaluative uses, especially when the N1 can be equally felicitously replaced with a standard quantifier as well as a negatively coloured collective nominal. Such ambiguous instances were nonetheless classified as (potential) PQUs. 
(4) Ranking francuskiej organizacji to sterta bzdur. [NKJP]

'The ranking prepared by the French organization is a pile of idiocies.'

The final step consisted in the determination of the proportions of abstract $\mathrm{N} 2 \mathrm{~s}$ which can be linked to paper metonymy, i.e. chiefly epistemic and evidential nominals, e.g. information, data, evidence, items denoting concepts related to money, specifically banknotes, e.g. $\operatorname{debt}(s)$ and loans, as well as nouns standing for communicative acts customarily expressed in paper form, e.g. offers, and those susceptible to verbalization, e.g. problems, for each of the analysed QNs in relation to all of its abstract N2-collocates in PQUs. ${ }^{15}$

\subsection{Results}

Prior to an analysis of the abstract nominals with which pile, stack, sterta 'pile' and stos 'stack' have been found to co-occur, it should be reiterated that what all of these QNs have in common is that in the concrete domian, they exhibit a marked predilection for N2-collocates referring to paper stuff, such as papers, books, documents, letters, newspapers, or banknotes (and their respective Polish counterparts). Essentially, this pronounced tendency in large measure dictates the direction of the N1s' collocational expansion.

The following table presents the results of a quantitative analysis of the extent to which each of the scrutinized items has delexicalized, based on the proportion of its purely quantificational uses involving abstract N2-collocates in relation to the total number of its attestations in the binominal ' $\mathrm{N} 2$ (of) N2(.GEN)'-construction, including also those with concrete noun collocates:

Table 1. PQUs with abstract N2-collocates

\begin{tabular}{|c|c|c|c|c|}
\hline \multicolumn{2}{|c|}{ QN } & $\begin{array}{c}\text { Total number of } \\
\text { attestations }\end{array}$ & $\begin{array}{c}\text { PQUs with abstract } \\
\text { N2s }\end{array}$ & $\begin{array}{c}\text { \% of PQUs with } \\
\text { abstract N2s }\end{array}$ \\
\hline \multirow{4}{*}{ English } & pile & 2219 & 55 & $2.48 \%$ \\
\cline { 2 - 5 } & piles & 992 & 15 & $1.51 \%$ \\
\cline { 2 - 5 } & stack & 693 & 22 & $3.17 \%$ \\
\cline { 2 - 5 } & stacks & 442 & 22 & $4.98 \%$ \\
\hline \multirow{4}{*}{ Polish } & sterta 'pile' & 987 & 5 & $0.51 \%$ \\
\cline { 2 - 5 } & sterty 'piles' & 553 & 1 & $0.18 \%$ \\
\cline { 2 - 5 } & stos 'stack' & 924 & 23 & $2.49 \%$ \\
\cline { 2 - 5 } & stosy 'stacks' & 915 & 5 & $0.55 \%$ \\
\hline
\end{tabular}

${ }^{15}$ It should be underlined that the scrutinized data were double-checked with a view to minimizing the risk of accidental inaccuracies in the classification or numbering of the extracted examples. 
What may be viewed as quite surprising is that stos 'stack' has been shown to display a higher percentage of quantifier uses than pile, even though the quantifier sense is entrenched only in the case of the latter. Yet, it should be added that pile has been observed to function as a quantifier in relation to a larger number of animate nouns than the Polish QN: there are nine collocates of this kind attested for pile, and only one for stos 'stack. Thus, on closer inspection, it turns out that it is pile that generally has delexicalized to a minimally larger degree than stos 'stack' $(2.88 \%$ vs $2.60 \%)$. Another difference lies in the semantic diversity of the $\mathrm{N} 2$-collocates of both items, as will be demonstrated in the following sections.

\subsubsection{Pile(s)}

According to CEDEL (p. 1185) and OnED, the noun pile entered the English language in the early $15^{\text {th }}$ century as a borrowing of Latin pila 'stone barrier; pillar; pier. Thus, the borrowed item originally referred to pillars and piers of bridges, whereas the sense of a vertical aggregate of objects was first attested in the mid- $15^{\text {th }}$ century. Currently, pile is defined as follows:
pile
(i) a number of things that have been placed on top of each other
(ii) a mass of something that is high in the middle and wider at the bottom than at the top
(iii) (informal) a lot of something
(iv) the short threads, pieces of wool, etc. that form the soft surface of carpets and some types of cloth such as velvet
(v) a large wooden, metal or stone post that is fixed into the ground and used to sup- port a building, bridge, etc.
(vi) (formal or humorous) a large impressive building (OALD, p. 1146)

As can be noted, pile has over time developed a few novel meanings, among which is the general sense of a large quantity. Definition (iii) clearly suggests that pile(s) of is semantically equivalent to the more frequent complex quantifier lot $(s)$ of and therefore should exhibit comparable collocational freedom. However, this is not the case, as corroborated by the empirical data. More specifically, it is still rather infrequent for pile(s) of to co-occur with abstract $\mathrm{N} 2 \mathrm{~s}$, and moreover, most of the detected instances of such uses can be seen as relying on paper metonymy:

Table 2. PQUs of pile(s) connected with paper metonymy ${ }^{16}$

\begin{tabular}{|c|c|c|c|}
\hline N1 & PQUs with abstact N2s & Paper metonymy uses & \% of paper metonymy uses \\
\hline pile & 55 & 29 & $52.73 \%$ \\
\hline piles & 15 & 11 & $73.33 \%$ \\
\hline
\end{tabular}

${ }^{16}$ For convenience, the figures pertaining to the PQUs of each item with abstract N2-collocates, already provided in Table 1 , are repeated in Tables $2-5$. 
As shown in the above table, almost $53 \%$ of the identified instances of pile's purely quantificational uses in the binominal ' $\mathrm{N} 1$ of $\mathrm{N} 2$ '-construction with abstract nominals can be traced to paper metonymy, and the figure is even higher in the case of the plural form, as approximately $73 \%$ of the relevant occurrences of piles may be subsumed under the category at issue. What follows is a qualitative discussion of the results for pile and piles, illustrated with a handful of representative examples. ${ }^{17}$

\section{a) Pile}

Among the examples of pile's PQUs involving abstract collocates associable with paper metonymy are nouns such as questions (5) and suppositions (6):

(5) Five little words that only raised a whole pile of other questions. He would have the answers, though, he vowed grimly. [BNC]

(6) And we need we need to make sure that we don't embark upon this new plan based on a whole pile of suppositions which in fact er lie in a world of fantasy. [BNC]

In (5), it is clear that the abstract $\mathrm{N} 2$ questions does not refer to enqueries expressed in paper form, with pile solely evoking a conceptual image of numerous sheets of paper placed on top of one another. Thus, this use appears to have been enabled by the associative link which exists between such epistemic concepts and the way in which they are commonly represented, namely by means of (pieces of) paper. Interestingly, the example under analysis likewise plays on the concrete and the abstract sense of the verb raise: when used in relation to a literal pile, raise is more or less synonymous with construct or build up, while employed with reference to abstract concepts such as questions, it means 'broach; bring up'. Nevertheless, what is foregrounded in the phrase $a$ whole pile of other questions is the multiplicity of the N2-referents, as evidenced by the quantification-reinforcing item whole, modifying the N1. The same holds for (6), wherein the presence of the aforementioned adjective suggests that rather than referring to a concrete set of entities, the speaker focuses on the plurality of the suppositions which need not even be expressed on paper.

\section{b) Piles}

As already mentioned, the plural form of the analysed QN displays analogous collocational patterns:

(7) There will be low blows and unfair accusations. From the proponents of the Charlottetown accord, Albertans can expect to be given piles of information explaining

${ }^{17}$ Due to space limitations, it is impossible here to provide an exhaustive list of the N2collocates of the discussed items identified in the data. 
the agreement, bumper stickers, lapel pins and Canadian flags to display in windows. Advocates imagine rows of red lawn signs in the shape of a maple leaf with a big YES emblazoned on the front. [CAN]

(8) In addition to these problems, Brazil has a relatively new and even more pressing problem - piles and piles of debt. [TIME]

The underlying metonymic basis is especially evident in (7), where the N2 information may well be taken to refer to the abstract entity itself, yet it is inferrable from the context that the data will probably be conveyed on paper. In (8), in turn, piles and piles of debt stands for a considerable degree of the abstract notion of indebtedness, without there being any vertically arranged sets of banknotes. Also noteworthy here is that the size implications of pile are amplified iconically, namely by repeating the pertinent form.

\subsection{2. $\operatorname{Stack}(s)$}

According to CEDEL (p. 1501) and OnED, the noun stack is a borrowing of Old Norse stakkr '(hay)stack'. In Middle English, the item was first used in the sense 'pile; heap; group of objects'. Today, stack is defined in the following way:

stack

(i) a pile of something, usually neatly arranged

(ii) (informal, esp. BrE) a large number or amount of something; a lot of something

(iii) a tall chimney, especially on a factory

(iv) 'the stacks' $(p l$.) the part of the library, sometimes not open to the public, where books that are not often needed are stored

(v) (computing) a way of storing information in a computer in which the most recently stored item is the first to be retrieved

(vi) $(g e o \log y)$ a tall thin part of a cliff that has been separated from the land and stands on its own in the sea (OALD, p. 1499)

Similarly to pile, also stack has by now acquired a number of additional senses, of which the most significant in the context of the present study is (ii), i.e. the pure quantity meaning. Yet, in contrast to lot (s) of, both pile(s) of and stack(s) of exhibit a rather narrow collocational scope in the abstract domain, with a majority of their N2-collocates of this kind standing for concepts metonymically connected with concrete paper stuff:

Table 3. PQUs of stack(s) connected with paper metonymy

\begin{tabular}{|c|c|c|c|}
\hline N1 & PQUs with abstact N2s & Paper metonymy uses & \% of paper metonymy uses \\
\hline stack & 22 & 16 & $72.73 \%$ \\
\hline stacks & 22 & 12 & $54.55 \%$ \\
\hline
\end{tabular}


As can be seen in Table 3, ca 73\% of the identified PQUs of stack involving abstract N2-collocates may be viewed as relying on paper metonymy, while for stacks, the figure stands at nearly $55 \%$. Below is a brief qualitative discussion of these findings.

\section{a) Stack}

The following are a few examples of the (potentially) purely quantificational uses of stack which may be linked to the conceptual mechanism under discussion:

(9) A lot of the problem has been down to selective quoting or misquoting of the evidence, and a lack of desire to embrace the stack of evidence that does not support the cholesterol hypothesis. [CORE]

(10) The dancers come from all across the Spanish-speaking world: from Argentina, Venezuela, Spain, and, above all, from Cuba, in a contingent that ranges from the veteran Carlos Acosta of the Royal Ballet down to newcomer Sarabia (who is considering a stack of offers while staying in Pompano Beach, Fla., with a former teacher, also a defector). [TIME]

Significant in (9) is the polysemous character of both the N1 stack and the verb embrace: even though the intended meaning of the phrase embrace the stack of evidence that does not support the cholesterol hypothesis is that of accepting a great amount of proof as such, it may simultaneously invoke the literal act of putting one's arms around a vertically arranged set of, e.g., documents. In (10), by contrast, one possible reading is that the actor referred to was considering offers expressed on sheets of paper, perhaps laid one on top of another, whereas the other scenario involves his choosing from among many offers, which need not be printed out on paper.

\section{b) Stacks}

As pointed out before, the metonymic motivation likewise applies to the plural form of the analysed item, which can be illustrated with the following examples:

(11) The secondary schools are still so rigidly academic that only about one in every four children gets into them. [...] Many must memorize stacks of Greek and Latin verbs, know how to translate Seneca and Tacitus, analyze (in English) the works of De Quincey, Ruskin and George Eliot, be familiar with everything from the Penses of Pascal to the characters of Corneille. [TIME]

(12) The crash grimly underscored the stacks of longstanding complaints about the U.S.'s air traffic control systems: CAA and military ground control are poorly coordinated, wield separate authority over an overcrowded air space (11,000 planes fly the U.S. skies in any hour of the day), and CAA itself is badly understaffed and underequipped. [TIME] 
In (11), the focus is clearly on the extortionate requirements levelled at the students, including the necessity to acquire a plenitude of Greek and Latin vocabulary, whereas the existence of actual stacks composed of sheets of paper on which the lexical items have been concretized bears little relevance. The constellation feature of stacks is also considerably backgrounded in (12), since, as can be inferred from the context, the intended message is that the accident at issue opened the public's eyes to the gravity of the many repeated criticisms of the American air traffic control systems. Thus, whether there were any literal stacks, and whether the complaints had been expressed in paper form at all appears less significant than the implied contrast between the large number thereof and the authorities' reluctance or incapacity to address the reported problems successfully.

\subsubsection{Sterta/sterty 'pile/piles'}

According to SEJP (p. 577), sterta 'pile' is probably a borrowing of Lithuanian stirta 'haystack'. In the $15^{\text {th }}$ century, the item was first attested in the sense 'heap; stack. Currently, sterta 'pile' is defined as follows:

\section{sterta}

(i) many objects lying one on top of another in a disorderly manner ${ }^{18}$

(ii) sheaves of grain or straw forming a stack (SJP PWN)

Even though the pure quantity meaning is not listed in the item's dictionary definitions, the corpus data reveal that it is not impossible for it to be employed solely with reference to a considerable number of what the accompanying abstract nominal refers to, with the arrangement feature being backgrounded to the benefit of purely scalar inferences. This observation links the Polish noun with the near-synonymous English ones discussed earlier, both of which have already established themselves as quantifiers. Still, as could be expected given the difference in the conventionalization of the pure quantity senses, PQUs of sterta 'pile' involving abstract N2s are attested substantially less frequently:

${ }^{18}$ As also noted by one of the anonymous reviewers, since the lexical make-up of sterta 'pile' includes the feature of disorderly arrangement, it may be supposed to possess a delexicalization potential comparable to that of the English QN heap or its Polish counterpart kupa 'heap'. However, as against the latter nouns, the former item lacks what Brems (2011: 156) calls "a horizontal meaning component." More specifically, in the concept of sterta 'pile', verticality appears to be a more prominent quality than is the case with that of kupa 'heap', as mirrored in a slight, yet meaningful difference in how both nouns are defined in SJP PWN: whereas for kupa 'heap', the relevant entities are described as leżace na sobie 'heaped together', sterta 'pile' is prototypically employed in relation to aggregates of many objects lying one on top of another (Polish jeden na drugim). In other words, the latter definition implies a higher degree of vertical regularity of ordering, which finds reflection in the pertinent item's predilection for countable N2-collocates and its restricted compatibility with mass nominals. 
Table 4. PQUs of sterta/sterty 'pile/piles' connected with paper metonymy

\begin{tabular}{|c|c|c|c|}
\hline N1 & PQUs with abstact N2s & Paper metonymy uses & $\begin{array}{c}\text { \% of paper metonymy } \\
\text { uses }\end{array}$ \\
\hline sterta 'pile' & 5 & 4 & $80 \%$ \\
\hline sterty 'piles' & 1 & 1 & $100 \%$ \\
\hline
\end{tabular}

The above table reveals that only five instances in which sterta 'pile' may be assumed to function purely quantificationally in relation to abstract N2s have been detected in the data, and the number is even lower for the plural form, as there is merely one such attestation. It must be underlined, though, that most of the identified uses may be seen as relying on the metonymic mechanism under scrutiny.

\section{a) Sterta 'pile'}

Provided below are two out of the four examples in which sterta 'pile' quantifies over abstract N2s capable of being concretized by means of (pieces of) paper found in the corpus data:

(13) Mama przyjęła mnie całą stertą historii i historyjek, które mnie nic nie obchodzą. Dowiedziałam się, o czym mówiono na fajfie u kanoniczki Walewskiej, o czym u państwa Zdziechowskich i to jeszcze, że lekarze stwierdzili u wujka Kazia raka wątroby. [NKJP]

'Mom entertained me with a whole pile of stories and anecdotes that I'm not interested in at all. I got to know what was discussed during canoness Walewska's party and at the Zdziechowskichs', and learnt that uncle Kazio had been diagnosed with liver cancer.'

(14) Dzięki Coetzee’emu dostajemy całą stertę nazwisk autorów, których warto poznać, książek, które trzeba przeczytać.' [NKJP]

'Thanks to Coetzee, we get a whole pile of names of authors who are worth becoming familiar with, and of books that are must-reads.'

In (13), a larger context indicates that rather than standing for a literal pile consisting of, e.g., books, the phrase cała sterta historii i historyjek 'a whole pile of stories and anecdotes' refers to a large amount of news transmitted orally, and the scalar inferences are additionally enhanced by the adjective caly 'whole, which modifies the N1. The same modifier appears in (14), suggesting that what the speaker strives to emphasize is the multitude of names which we learn thanks to the writer in question, irrespective of their having been printed out on stacked sheets of paper or not.

\section{b) Sterty 'piles'}

As shown in Table 4, the sole example in which sterty 'piles' quantifies over an abstract noun identified in the data may be viewed as based on paper metonymy 
due to the tendency for pojęcia 'concepts/notions' to be expressed on (stackable) paper, e.g. in the form of glossaries:

(15) I rosnąć. I nie umierać a żyć. I wstawać prawą nogą w deszcz. I mielić w sobie sterty pojęć. [NKJP]

'And to grow. And not to die, but to live. And to get up on the right side of the bed in the rain. And to mince piles of concepts in your head.

Yet, as is also the case with a number of examples discussed earlier, (15) builds on polysemy. More precisely, even though the phrase mielić $w$ sobie sterty pojęć 'mince piles of concepts in your head' should be interpreted metaphorically as standing for the act of carefully pondering over numerous ideas, it may conjure up an image of literally grinding sheets of paper on which the notions have been expressed.

\subsubsection{Stos/stosy 'stack/stacks'}

According to SEJP (p. 578), stos 'stack' is a borrowing of German Stoss 'heap; pile', and was first attested in Polish in the $15^{\text {th }}$ century in the sense 'heap, pile; pile of wood for burning. Today, stos 'stack' is defined in the following way:

\section{stos}

(i) many things placed one on top of another

(ii) a pile of wood on which to burn something

(iii) death at stake

(iv) a pillar supporting the roof of a mine working

(v) a regular arrangement of pieces of wood of the same kind and typically of the same length $[\ldots]($ SJP PWN)

As Table 1 demonstrates, stos 'stack' has delexicalized to a larger extent than sterta 'pile, yet it also displays a preference for abstract N2s denoting concepts which can be concretized by means of, and thus conceptualized as, (stacked) pieces of paper:

Table 5. PQUs of stos/stosy 'stack/stacks' connected with paper metonymy

\begin{tabular}{|c|c|c|c|}
\hline N1 & PQUs with abstact N2s & Paper metonymy uses & $\begin{array}{c}\text { \% of paper metonymy } \\
\text { uses }\end{array}$ \\
\hline stos 'stack' & 23 & 20 & $86.96 \%$ \\
\hline stosy 'stacks' & 5 & 4 & $80 \%$ \\
\hline
\end{tabular}

As shown above, approximately $87 \%$ of the abstract nominals with which stos 'stack' co-occurs in its PQUs, and $80 \%$ of those co-appearing with stosy 'stacks', may be thought of as stemming from the discussed metonymic mechanism. In the following parts of this section, a closer look is taken at a few examples of such metonymically motivated uses. 
a) Stos 'stack'

Among the abstract N2-collocates of stos 'stack' which seem to have been recruited based on their conceptual relation to paper stuff are the nouns pytania 'questions' (16) and watpliwości 'doubts' (17):

(16) Piotr został sam, ze stosem pytań w głowie. [NKJP]

'Peter was left alone with a stack of questions in his head.'

(17) Gdy już wydaje się, że przejrzeliśmy zamysł twórcy i dotarliśmy do sedna filmu, Zelenka sprytnie podsuwa stos kolejnych wątpliwości. [NKJP]

'When it seems that we have finally become aware of the artist's design, Zelenka skillfully suggests a stack of further doubts.'

In (16), owing to the presence of the locative phrase $w$ gtowie 'in the head', it is clear that stos pytan' 'a stack of questions' refers solely to a large number of the abstract entities (cf. example (15)), without there being any actual stack. By contrast, (17) is another use which exploits the polysemous character of the N1 and the surrounding lexical elements: literally, the verb podsuwać means 'push nearer', while in its transferred sense, it is roughly synonymous with suggest, so that podsuwać stos kolejnych watpliwości 'suggest a stack of further doubts', although clearly employed with reference to the act of invoking a host of further skeptical reflections by the pertinent film director, may simultaneously conjure up an image of the viewer being confronted with an actual stack consisting of pieces of paper on which the doubts have been verbalized.

\section{b) Stosy 'stacks'}

Cited below are two out of the four identified examples in which stosy 'stacks' may be seen as functioning quantificationally in relation to abstract N2-collocates associatively linked to paper:

(18) Można podpisać papier i przekazywać bezwartościowe materiały i można niczego nie podpisywać i przekazywać stosy tajnych informacji. [NKJP]

'One may sign a document and convey worthless information, and one may convey stacks of secret information without having signed anything.'

(19) Sądy zawalone są stosami niezałatwionych spraw i wymagający specjalnej troski klient jest dopustem Bożym i prawdziwym utrapieniem. [NKJP]

'The courts are loaded with stacks of unsettled cases, so a client who requires special care is a scourge and a real nuisance.'

The shift from designating a specific configuration of pieces of paper to assessing the quantity of what they contain is particularly visible in the case of (18), in which the focus is on the large amount of certified information as such, with the arrangement feature inherent in the lexical make-up of stos 'stack' being of little consequence to the intended message. Analogously, the quantitative implicature is largely foregrounded to the detriment of the source, 
constellation-related meaning in (19), where it is implied that court clerks do not have time to attend to enquirers due to the high number of issues which urgently need to be dealt with, regardless of whether the associated paperwork is arranged into stacks or not. Notably, this example may likewise be looked at as playing on the concrete and the abstract senses of stos 'stack' and the verb zawalać 'load', which literally refers to placing numerous objects in a particular place, while figuratively it means burdening someone with an abundance of responsibilities.

\section{Conclusion}

As should be evident from the foregoing discussion, the delexicalization of the English nouns pile and stack as well as Polish sterta 'pile' and stos 'stack', operationalized as their collocational broadening attendant upon semantic generalization (cf. Brems 2003, 2011), is indeed facilitated by the conceptual contiguity which exists between their recurrent concrete collocates, typically referring to paper entities, and abstract concepts associatively related thereto. For this reason, the scrutinized items may be thought of as collocationally specialized compared with other, more schematic quantifiers, such as many/much or lot(s) of in English, and dużo/wiele 'many; much' or mnóstwo 'lot(s) of' in Polish.

The analysed nouns nonetheless differ in the extent to which they rely on what is labelled here as paper metonymy. According to the assumed hypothesis, this kind of metonymization has turned out to be more productive in the case of the Polish QNs, whereas given the entrenchment of the English items' quantifier meaning, it should not come as a surprise that the latter's collocational scatter is conspicuously wider, encompassing not only chiefly epistemic and evidential nouns, but also, e.g., activity- and event-denoting N2s, e.g. gold exploration, races and transfers of water, as well as psychological mass nominals such as guilt, gusto or inconvenience, none of which appears to have been employed alongside pile and stack by virtue of its associative relation to any stackable concrete entities. In view of the high proportions of paper metonymy uses attested for the emergent Polish quantifiers sterta 'pile' and, in particular, stos 'stack', the synchronic Polish data may be taken to provide further support for Brems' (2003) proposal that such items' collocational expansion into abstract contexts is motivated metonymically, and that this cognitive mechanism promotes their purely quantificational uses, thus paving the way for the incorporation of an increasing number of other semantic types of abstract N2s. The QN stos 'stack', for instance, has been found to co-occur with the N2s przykrości i prawdziwe zaiste wypadki 'nuisances and indeed real accidents' and przypadki 'accidents', neither of which can be easily verbalized or otherwise directly connected with stackable paper stuff. 
In the light of the above, it can be expected that analogously to pile and stack, stos 'stack', and possibly also sterta 'pile', will in the long run continue to loosen their selectional restrictions by allowing abstract N2s, especially of the mass kind, which cannot be regarded as springing from the conceptual mechanism under consideration. As a matter of fact, Internet data demonstrate that the collocability of both Polish QNs in the abstract domain is somewhat wider than what the corpus searches have revealed, which can be looked at as evidence of their growing schematicity, e.g.:

(20) A wyborcy mieliby stertę czasu na zastanowienie się.

[https://www.salon24.pl/u/predatorxl/283806,wzmacnianie-demotfukracji]

'And the voters would have a pile of time to ponder over it.'

(21) Serwis ukazuje wpisy, które przynoszą dobrą zabawę oraz stertę uśmiechu.

[http://kataloga.pl/roznosci/www,megademoty,pl,s,3678.html]

'The portal presents posts that bring fun and a pile of smiling.'

(22) kazda bessa sie musi skonczyc, wiec jak ktos ma stos cierpliwosci to moze ja przetrzymac

[https://blogi.bossa.pl/2009/02/17/polemika-z-pseudo-analiza/]

'Every slump must come to an end, so if you have a stack of patience, you can endure it.'

(23) A tu wciąż widzimy jak piłka leci w powietrzu godzinę, w czasie której przeciwnik ma stos czasu żeby się ustawić.

[http://www.widzewiak.pl/komentarze/newsroom,14495,Wypowiedzi-po-meczu-GKPGorzow---Widzew]

'And here we still see the ball flying through the air for an hour during which the opponent has a stack of time to take up the right position.'

However, such uses still have a rather creative, unconventional character and are confined to highly informal registers. It remains therefore to be seen whether the Polish nouns will gain a stronger foothold in the realm of absolute quantification by increasing their co-occurrence with $\mathrm{N} 2 \mathrm{~s}$ such as the ones above, as has been the case with the semantically related QN kupa 'heap' (cf. Schabowska 1962, 1967), which has already acquired the additional purely quantificational sense (cf. SJP PWN; USJP). Considering the fact that language users generally display a propensity to look for novel, extravagant means of expression of old meaning contents (Haspelmath 1999), sterta 'pile' and stos 'stack' may at some point supersede the now more canonical QNs, such as the above-mentioned kupa heap' or masa 'mass', in the process of renewal (cf. Brems 2011), provided that the latter gradually lose their expressive vigour. 


\section{References}

Biber Douglas, Johansson Stig, Leech Geoffrey, Conrad Susan, Finegan Edward (1999). Longman Grammar of Spoken and Written English. London: Longman.

BREMS Lieselotte (2003). Measure noun constructions: An instance of semanticallydriven grammaticalization. International Journal of Corpus Linguistics 8(2), 283-312.

Brems Lieselotte (2011). The Layering of Size Noun and Type Noun Constructions in English. Berlin: Mouton de Gruyter.

Delbecque Nicole, Verveckken Katrien (2014). Conceptually-driven analogy in the grammaticalization of Spanish binominal quantifiers. Linguistics 52(3), 637-684.

Derwojedowa Magdalena, Kopcińska Dorota (2009). Czy warto restytuować zaimki liczebne? Biuletyn Polskiego Towarzystwa Jęzkoznawczego 65, 175-188.

Doroszewski Witold (1952). Podstawy gramatyki polskiej. Warszawa: Państwowe Wydawnictwo Naukowe.

FEYAERTS Kurt (2003). Refining the inheritance hypothesis: interaction between metaphoric and metonymic hierarchies. In Metaphor and Metonymy at the Crossroads: A Cognitive Perspective, Antonio Barcelona (ed.), 59-78. Berlin: Mouton de Gruyter.

Haspelmath Martin (1999). Why is grammaticalization irreversible? Linguistics 37(6), 1043-1068.

HeIne Bernd (2003). Grammaticalization. In The Handbook of Historical Linguistics, Richard D. JANDA, Brian D. JosEPH (eds.), 575-601. Oxford: Blackwell.

Hopper Paul J. (1991). On some principles of grammaticization. In Approaches to Grammaticalization: Volume 1, Elizabeth C. Traugott, Bernd Heine (eds.), 1735. Amsterdam-Philadelphia: John Benjamins.

Hopper Paul J., Traugott Elizabeth C. (2003). Grammaticalization. $2^{\text {nd }}$ edition. New York: Cambridge University Press.

KozıoŁ Joanna (2016). Liczebniki nieokreślone w opisie językoznawczym i praktyce leksykograficznej - zarys problematyki. Prace Językoznawcze 18(1), 93-102.

Kövecses Zoltán (2010). Metaphor: A Practical Introduction. 2nd edition. New York: Oxford University Press.

LANGACKer Ronald (1991). Foundations of Cognitive Grammar: Volume 2: Descriptive Application. Stanford: Stanford University Press.

LAsKowski Roman (1984). Liczebnik. In Gramatyka współczesnego języka polskiego: Morfologia, Renata Grzegorczykowa, Roman LAskowski, Henryk Wróbel (eds.), 283-293. Warszawa: Państwowe Wydawnictwo Naukowe.

LEHMANN Christian (1985). Grammaticalization: Synchronic variation and diachronic change. Lingua e Stile 20, 303-318.

Nerlich Brigitte (2006). Metonymy. In Concise Encyclopedia of Semantics, Keith ALLAN (ed.), 550-554. Oxford: Elsevier.

Qurik Randolph, Greenbaum Sidney, Leech Geoffrey, Svartvik Jan (1985). A Comprehensive Grammar of the English Language. London/New York: Longman.

Radden Günter, Dirven René (2007). Cognitive English Grammar. Amsterdam: John Benjamins.

Schaвowska Maria (1962). O formalnej numeralizacji rzeczowników. Język Polski 42(2), 116-124.

SchaвowsKa Maria (1967). Rzeczowniki ilościowe w jezzyku polskim. Wrocław: Ossolineum. 
Schabowska Maria (1970). Liczebnik nieokreślony trochę. Język Polski 50(2), 110-118.

SiUCIAK Mirosława (2008). Kształtowanie się kategorii gramatycznej liczebnika w języku polskim. Katowice: Wydawnictwo Uniwersytetu Śląskiego.

SweEtser Eve E. (1988). Grammaticalization and semantic bleaching. In Proceedings of the Fourteenth Annual Meeting of the Berkeley Linguistics Society, Shelley Axmaker, Annie JaIsSER, Helen Singmaster (eds.), 389-405. Berkeley: Berkeley Linguistics Society.

Traugott Elizabeth C., Trousdale Graeme (2013). Constructionalization and Constructional Changes. Oxford: Oxford University Press.

\section{Corpora}

BNC = DAviEs Mark (2004-). BYU-BNC. (Based on the British National Corpus from Oxford University Press). [URL: http://corpus.byu.edu/bnc/; accessed October 5, 2017]

CAN = The Strathy Corpus of Canadian English (n.d.). [URL: http://corpus.byu.edu/ can/; accessed October 5, 2017]

CORE = DAvies Mark (2016-). Corpus of Online Registers of English (CORE). [URL: http://corpus.byu.edu/core/; accessed October 5, 2017]

NKJP = BAńko Mirosław, Górski Rafał L., Lewandowska-Tomaszczyk Barbara, Łaziński Marek, Pęzik Piotr, Przepiórkowski Adam (2008-2012). Narodowy Korpus Języka Polskiego. [URL: http://nkjp.pl/poliqarp/; accessed October 5, 2017] TIME = DAviEs Mark (2007-). TIME Magazine Corpus: 100 million words, 1920s2000s. [URL: http://corpus.byu.edu/time/; accessed October 5, 2017]

\section{Dictionaries}

CEDEL = KLEIN Ernest (1967). A Comprehensive Etymological Dictionary of the English Language: Volume II L-Z. Amsterdam/London/New York: Elsevier.

ISJP = BAŃKo Mirosław (ed.) (2000). Inny słownik języka polskiego. Warszawa: Wydawnictwo Naukowe PWN.

OALD = TuRnBull Joanna (ed.) (2010). Oxford Advanced Learner's Dictionary of Current English. $8^{\text {th }}$ edition. Oxford: Oxford University Press.

OnED = HARPer Douglas (2001-2018). Online Etymology Dictionary. [URL: http:// www.etymonline.com; accessed 30 September 2017]

SEJP = BoRYś Wiesław (2005). Słownik etymologiczny języka polskiego. Kraków: Wydawnictwo Literackie.

SJP PWN = Słownik języka polskiego PWN. [URL: http://sjp.pwn.pl; accessed 30 September 2017]

USJP = DUBISz Stanisław (ed.) (2003). Uniwersalny słownik języka polskiego: Tom 4: $R-V$. Warszawa: Wydawnictwo Naukowe PWN.

Instytut Filologii Angielskiej

Uniwersytet Jagielloński

al. Mickiewicza 9A

31-120 Kraków

[damian.t.herda(at)gmail.com] 